\title{
The Effect of Cocoa Paste Percentage of Fermented Cocoa Beans on the Sensory Characteristic of Chocolate Bars
}

\author{
Wahyu Margono ${ }^{1, *}$, Mustamin A. Masuku ${ }^{1}$, Nurjana Albaar ${ }^{1}$, \\ Tamrin $^{2}$, Suryati Tjokrodiningrat ${ }^{3}$
}

${ }^{1}$ Department of Food Technology, Faculty of Agriculture, Khairun University, Ternate, Indonesia

${ }^{2}$ Department of Food Science and Technology, Faculty of Agriculture, Universitas Halu Oleo, Kendari, Indonesia

${ }^{3}$ Department of Agrotechnology, Faculty of Agriculture, Khairun University, Ternate, Indonesia

*Corresponding author. Email: wahyumargono.01@gmail.com

\begin{abstract}
This study aims to obtain optimal chocolate bars according to sensory tests based on the percentage of cocoa paste. The research carried out in stages, namely the selection of fermented dried cocoa beans according to SNI 01-2323-2008, making the cocoa paste, and treating 30\% and $60 \%$ cocoa paste on chocolate bars. This research conducted from August to September 2018, at Halu Oleo University, Kendari, Southeast of Sulawesi. Testing the treatment of the percentage of cocoa paste on chocolate bars is sensory. Sensory testing includes taste, color, aroma, and texture. The best sensory test results are then determined as the best treatment then tested for antioxidants and proximate content. Antioxidants testing uses the DPPH method. The analysis of variance ( $F$ test) used to determine the influence of cocoa paste to sensory characteristics. The average difference test uses the Duncan Multiple Range Test (DMRT) at the significance level $\alpha=0.05$. The relationship between the percentage of pasta with sensory characteristics using correlation analysis and simple regression. The contribution of simultaneous treatment to chocolate sensory characteristics analyzed using the stepwise multiple linear regression method. The results show that the percentage of cocoa paste significantly affects the sensory characteristics of chocolate bar flavor. The hedonic tests show that panelist preference is the chocolate bars with a percentage of $30 \%$ cocoa paste.
\end{abstract}

Keywords: chocolate bars, cocoa, cocoa paste percentage, sensory test

\section{INTRODUCTION}

Indonesian chocolate generally produced using additives in the form of a cocoa paste of less than 30 percent. Some countries, such as America and Europe, require chocolate about more than 45 percent of cocoa paste content (Anonimous, 2018). Chocolate with a mixture of cacao pastes more than 45 percent is good for health because of its very high antioxidant content. Chocolate production actually must refer to SNI 7934: 2014, the standardization of chocolate and chocolate products, so that the role of chocolate antioxidants for health such as reducing cholesterol in the blood, as well as hypoglycemic compounds for diabetes mellitus, can be maintained. The accuracy of cocoa bean processing and determining the percentage of cocoa paste in chocolate influence the antioxidant content of chocolate bars.

North Maluku chocolate consumption until 2017 is 6.6 tons per year, and tends to increase around 1.5 percent per year. Increased consumption of chocolate encourages the production of food and drinks made from chocolate. But the increase in chocolate consumption is not supported by the regional cocoa and chocolate paste processing industry.
The Ministry of Industry noted, in 2016 there were more than 4,000 industries in North Maluku Province. 45.7 percent of the industry is the food industry. 37.8 percent of the food industry is engaged in the chocolate-based industry. However, until 2019, the processing industry of cocoa beans into cocoa in North Maluku did not yet exist (Kemenperin, 2019).

Cocoa beans contain levels of flavonoids (Kofink, et al., 2007), and contain chemical components that contain cocoa fat, polyphenols (flavonoids), theobromine (in small amounts), caffeine, and pectin (Towaha, et al., 2012; Hii et al., 2009; Utami, 2018), and fatty acids (Ristanti et al., 2016). This chemical component influences the unique taste of cocoa. In addition to having unique flavors, the benefits contained in cocoa beans for health are enormous and have been widely approved. (Ackar, et al., 2013; Ruzaidi et al., 2008), suggested that cocoa beans contain hypoglycemic components, which have the potential in diets of diabetics. Towaha, et al., (2012) stated that cocoa polyphenols have links with antioxidants, anti-microbial, immuno-modulator, chemo-preventive effects, diuretic 
effects, anti-hypertension, anti-inflammatory, stress, prevention of dental caries, changing use for hemolysis, healthy heart. Based on the activity of the chemical component and the unique taste, the benefits of cocoa beans are very broad as raw material for food, beverages, and biopharmaceutical preparations (Ristanti et al., 2016; Towaha, 2012; Belščak et al., 2009; Wells, 2009; Lambert, 2009; Anonim, 2008).

\section{MATERIALS AND METHODS}

\section{Materials}

This research uses several materials which classified into the main ingredients and supplementary materials. The main ingredients are fermented cocoa beans (Grade A according to SNI 01-2323-2008) of $15 \mathrm{~kg}$, cocoa nib, and cocoa paste. Additional ingredients, namely, cocoa butter, sucrose sugar, milk powder, seaweed flour, and vanilla.

\section{Equipment}

This study uses of cocoa dryer as roasting machine with a $15 \mathrm{~kg}$ capacity, a rough crank machine for nib (stone mill), a fine ballast machine (ball mill) with capacity of about 30 and $10 \mathrm{~kg}$, manual scale weighing $15 \mathrm{~kg}$, an analytical balance, digital thermometer, ceramic (for tempering uses) about $3 \mathrm{~kg}$ size, measuring cup, frying pan, filter, gas stove, cutter, camera, thermometer, timer, 350 watt of mini heater, and stationery documentation.

\section{Chocolate Paste Making}

Pembuatan pasta kakao terdiri dari dua tahap yaitu pasta kasar dan pasta halus merujuk pada Wahidin, et al., (2017) Tahapan pembuatan pasta kakao adalah sebagai berikut: Making cocoa paste consists of two stages, namely coarse and fine paste. Making cocoa paste refers to Wahidin, et al., (2017). The stages of making cocoa paste are as follows:

(1). As much as $7.5 \mathrm{~kg}$ of Cocoa Nib is added to the stone mill as slowly. The resulting stone mill is a rough paste. A rough paste will be for further into fine processing.

(2). The rough paste obtained from the first stage is then mashed, using a ball mill to get about 200 mesh of fine paste. Paste smoothing takes time for 4 hours. Smooth paste in the form of thick liquid, dark brown and shiny. The result of this stage is cocoa paste. The process of making cocoa paste follows Wahidin, et al., (2017).

\section{Chocolate Bars Making}

Making chocolate bars uses a combination of ingredients consisting of the main ingredient and a mixture of ingredients. Chocolate bar mixture ingredients refer to Tamrin, 2013. The making is a continuation of the manufacture of cacao bar paste, with a series of activities, namely:

(1). Mix ingredients for chocolate bars using $30 \%$ and $60 \%$ cocoa paste, together with additives in the form of sucrose sugar, cocoa butter, seaweed flour and vanilla (flavoring agent) according to the percentage of cocoa paste treatment.
(2). All ingredients listed in point 1 , mixed according to each treatment, using a mixer with a comparison of ingredients following Wahidin et al, 2017).

(3). Mix the ingredients of chocolate paste then put and grind in the ball mill to produce chocolate dough.

(4), The chocolate mixture is then tempered to obtain the melting point of the cocoa butter crystals. Tempering is the process of obtaining stable chocolate, which is chocolate with a small fat crystal with a stable melting point in the temperature range of $31-35^{\circ} \mathrm{C}$. Tempering is a treatment related to temperature regulation. Through the tempering process, glossy and brittle chocolate products will be produced, and avoid blooming. Cocoa paste removed from the ball mill has a temperature of $50^{\circ} \mathrm{C}$ and then allowed to stand for 15 minutes on a ceramic container. After 15 minutes, the temperature of the cocoa paste drops to 28-29 ${ }^{\circ} \mathrm{C}$.

(5). Continuation of the tempering process is constant stirring where the temperature of the cocoa paste rises to around $32-33^{\circ} \mathrm{C}$. The purpose of temperature raising is to melt all the unstable crystals and leave the stable crystals. Constant stirring for 45 minutes and brown fat is formed with the most stable $\beta$ type crystals and has a melting point of $34-35^{\circ} \mathrm{C}$ (Ribeiro et al., 2012).

(6). The next step is printing chocolate bars on the printing containers. The temperature of the liquid chocolate maintained at the range $32-33^{\circ} \mathrm{C}$ during printing. After the liquid chocolate placed perfectly in the container, the next is compaction or compression of chocolate manually.

\section{Hedonic Test}

Hedonic chocolate bar testing is performed on all treatment combinations with complete composition, namely, chocolate bars R1P1, R1P2, R2P1, and R2P2. The overall chocolate bar combination was tested at a preferred level (hedonic test), including tests of taste, color, aroma, and texture according to Wahidin et al., (2017), Tarigan and Towaha, (2015). The hedonic test carried out to obtain the level of panelist preference for physical and physical chocolate bars. The hedonic scale of the results of the panelists' response changed to a numerical scale with a quality score according to preference level (1-5). The change intended so that the numerical data can be analyze statistically. The hedonic testing is following the SNI 012346-2006 procedure, concerning organoleptic and/or sensory testing instructions by the National Standardization Agency (BSN).

Panelists are students of U.H.O, who belong to the group of rather trained (non-standard) panelists. Panelist selection is using the criteria of, having completed the sensory organoleptic test subjects, chocolate enthusiasts, and the panelist's conditions were not hungry or full. For these criteria, sensory testing was running at 09.00-11.00 WITA. The timing of testing based on the local time habits. Testing using 45 panelists. The panelists received prior training by trained trainers from U.H.O before asked to give their responses about likes or dislikes interpreted in the form of a scale of preference for each test variable. 
Hedonic testing carried out at the Laboratory of Faperta U.H.O. Chocolate bar samples presented in the form of rectangular pieces (according to the original form of chocolate bar production). Samples randomly presented one by one.

\section{Data Analysis}

Data analysis performed on the research variables. The determination of variables made refers to Tamrin (2012), Tamrin (2013). The measured variable is the characteristics of a chocolate bar, which consists of the characteristics of taste, color, aroma, and texture of food and drink concerning Misnawi and Jinab (2008) based on hedonic tests, on a scale of 1-5 ratings. This test carried out in the THP laboratory of Haluoleo University, Kendari. Likewise, the test variables include liking for taste, liking for color, liking for smoothness (texture), and liking for aroma (flavor). All chocolate treatments are organoleptically test, by presenting samples one by one, to avoid assessment bias. In a taste preference test, panelists assessed chocolate by feeling and swallowing. To neutralize the panelists' sense of taste, at each sample change, the panelists drink water first. The purpose of the taste test is to get the chocolate bar products that are most preferred by panelists. The overall test score based on panelist ratings of each characteristic or variable tested as stated in the score sheet. The test used 45 panelists who were somewhat trained. Panelists are students of the Faculty of Agriculture U.H.O.

The relationship among the percentage of cocoa paste with the characteristics of taste, color, texture, and aroma analyzed using correlation analysis and simple linear regression. Estimating the contribution of cocoa paste percentage to preferences, apply the multiple linear regression method or the stepwise procedure according to Sarle and Goodninght (1982). Data analysis using the SAS program ver.9.16 (SAS, 2013).

\section{RESULTS AND DISCUSSION}

Characteristics of Chocolate Bars Based on Hedonic Tests

The resulting cocoa paste of this study shows the performance of viscous liquid, dark brown, glossy, and smooth, indicated good quality paste. Ensuring the cocoa paste quality is very important before printing the chocolate bar, regarding the quality of the paste is one indication of the formation of stable crystals.

The taste characteristics using hedonic test shows that chocolate bars with the highest average value were treatments R1P1 with a value of 4.273 , and the lowest value is R2P2 treatment, the value is 2.756 . The same test on color characteristics show the highest value is the treatment R1P1 $(4,091)$, and the lowest in R1P2 $(3,848)$. The texture characteristics test shows the highest value found on treatment R1P1 (4.091), and the lowest is in the treatment $\mathrm{R} 2 \mathrm{P} 2$ (3.576). The aroma characteristic test results show that the highest value is the treatment R1P1 (4.240) and the lowest in treatment R2P2 (3.601). Panelist values were analyzed using analysis of variance (ANOVA) as shown in Table 1 .

Table 1. Summary results of various analyzes Percentage of cocoa paste in chocolate bars according to the hedonic test.

\begin{tabular}{|l|l|l|l|}
\hline $\begin{array}{l}\text { Characteristic } \\
\text { s / Variables }\end{array}$ & $\begin{array}{l}\text { Averag } \\
\text { e }\end{array}$ & $\begin{array}{l}\text { Coeff. } \\
\text { Variation }\end{array}$ & $\mathbf{P}>\mathbf{F}$ \\
\hline Taste & 3.6290 & 3.490616 & $0.0015^{* *}$ \\
\hline Colour & 3.9924 & 5.557239 & $0.8217^{\text {tn }}$ \\
\hline Texture & 3.7726 & 5.415913 & $0.1425^{\text {tn }}$ \\
\hline Aroma & 3.9696 & 4.827437 & $0.0605^{\text {tn }}$ \\
\hline
\end{tabular}

The summary analysis of variance shows that the percentage of cocoa paste has a very significant effect on the characteristics/variables of chocolate bar flavor, and has no significant effect on the characteristics of color, texture, and aroma. The percentage of cocoa paste is thus influencing the taste characteristics. Mean difference test of the effect of percentage of cocoa paste on chocolate flavor characteristics based on hedonic tests using Duncan's Multiple Range Test (DMRT) $\alpha$ level $=0.05$. A summary of the DMRT difference test is present in Table 2

Table 2. Different test the effect of the percentage of cocoa paste on the quality of chocolate bars based on the results of the hedonic test.

\begin{tabular}{|c|c|c|}
\hline \multirow{2}{*}{ Cacao Paste } & \multicolumn{2}{|c|}{$\begin{array}{c}\text { Characteristics of } \\
\text { Chocolate Bars }\end{array}$} \\
\cline { 2 - 2 } & \multicolumn{2}{|c|}{ Taste } \\
\hline P1 & 4.273 & $\mathrm{~b}$ \\
\hline P2 & 3.333 & a \\
\hline
\end{tabular}

Note: Numbers followed by letters are not the same in the same column and row as significantly different in the 0.05 DMRT test. $\mathrm{P} 1=$ percentage treatment of cacao paste $30 \%, \mathrm{P} 2=$ percentage treatment of cacao paste $60 \%$.

The test results in Table 2 show that the treatment of the percentage of cocoa paste on chocolate bars was significantly different in flavor characteristics, but not significantly different in color, texture, and aroma characteristics. The treatment with the highest hedonic preference found in $\mathrm{P} 1$, and the lowest hedonic preference was in P2. The different test results explained that the panelists' tendency towards taste found in $\mathrm{P} 1$.

The results study shows that the percentage of cocoa paste affects the taste sensory characteristics of the chocolate bars based on the hedonic test. Its effect very significant on the taste characteristics, but does not have a significant effect on the characteristics of color, texture, and aroma. The percentage of cacao paste $30 \%$ shows a positive relationship, while the cacao paste $60 \%$ shows a negative relationship with taste sensory characteristics. 


\section{REFERENCES}

[1] Ackar D., K.V. Lendić, M. Valek, D. Šubarić, B. Miličević, J. Babić,1 and I. Nedić. 2013. Cocoa Polyphenols: Can We Consider Cocoa and Chocolate as Potential Functional Food? Hindawi Publishing Corporation. Article ID 289392. J. of Chem. 2013. 7p. http://dx.doi.org/10.1155/2013/289392.

[2] Anonimous, 2018. Indonesia cacao and chocolater information site. https://cocoainfo.wordpress.com/2016/02/07/keb utuhan-kakao-dunia-meningkat.

[3] Anonimous, 2008. Panduan lengkap kakao. Manajemen agribisnis dari hulu hingga hilir.

[4] BSN. 2006. Petunjuk pengujian organoleptik dan atau sensori. SNI 01 2346-2006. Badan Standardisasi Nasional.

[5] BSN. 2008. Standar Nasional Indonesia Biji Kakao. SNI 2323:2008. Badan Standardisasi Nasional.

[6] BSN. 2014. Standar Nasional Indonesia Lemak Kakao. SNI 7934:2014. Badan Standardisasi Nasional.

[7] Hii, C.L., C.L.Law, S.Suzannah, Misnawi and M. Cloke. 2009. Polyphenols in cocoa (Theobroma cacao L.). J. Food. Ag-Ind. 2(04):702-722.

[8] Kartika, B. P. Hastuti, dan W. Supartono. 1988. Pedoman uji inderawi bahan pangan. Proyek peningkatan/pengembangan Perguruna Tinggi Universitas Gadjah Mada. Yogyakarta. pp 116.

[9] Kemenperin, 2019. http://kemenperin.go.id/artikel/16877/Kemenperi n-Angkat-Potensi-IKM-Maluku-Utara.

[10] Kofink, M., M. Papagiannopoulos and R. Galensa. 2007. (-)-Catechin in Cocoa and Chocolate: Occurence and Analysis of an Atypical Flavan-3-ol Enantiomer. Molecules. 12:1274-1288.

[11] Lambert, J.P. 2009. Nutrition and Health Aspects of Chocolate. in industrial chocolate manufacture and use. 4th edition. Beckett, S.T (ed). Blackwell Publishing Ltd. ISBN: 978-1-405-13949-6. 623$625 \mathrm{pp}$.

[12] Misnawi dan S. Jinap. 2008. Citarasa, Tekstur, dan Warna Cokelat dalam buku Panduan Lengkap KAKAO, dalam KAKAO, Manajemen Agribisnis dari Hulu hingga Hilir, Cetakan 1. Penebar Swadaya, Jakarta. hal 237-251.

[13] Ribeiro, A.P.B., R. Claro da Silva, L.A. Gioielli, M.I.de Almeida Goncalves, R. Grimaldi, L.A.D. Goncalves, \& T. Guenter Kieckbusch. (2012). Physico-chemical properties of Brazilian cocoa butter and industrial blends. Part I - Chemical composition, solid fat content and consistency. Grasas Y Aceites, Seville. 63(1), 79-88.
[14] Ristanti, E.Y., Suprapti dan D. Anggraeni. 2016. Karakteristik komposisi asam lemak pada biji kakao lindak dari12 daerah di Sulawesi Selatan. J. Industri Hasil Pertanian. 11(1):15-22.

[15] Ruzaidi, A. A. Maleyki, I. Amin, A. G. Nawalyah, H. Muhajir, M.B.S.M.J. Pauliena, and M.S. Muskinah. 2008. Hypoglycaemic properties of Malaysian cocoa (Theobroma cacao) polyphenols-rich extract. J. of Intenational Food Research. 15 (3):305-312.

[16] Tamrin. 2012. Perubahan aktivitas antioksidan bubuk kakao pada Penyangraian vakum. J. Ilmu dan Teknologi Pangan. Faperta Univ. Haluoleo. Proc. Insinas. 86-91.

[17] Tamrin. 2013. Analisis Tahap Pasca Penen Kakao dan Penurunan Kadar Antioksidan Katekin dalam Proses Pengolahan Bubuk Kakao. Seminar Nasional: Peranan Teknologi Pangan dan Gizi dalam Meningkatkan Mutu, Keamanan dan Kehalalan Produk Pangan Lokal. Padang Sumatra Barat, 9 November 2013. pp 11.

[18] Tarigan, Br., E., dan Towaha, J. 2015. Tingkat kesukaan cokelat susu batang produksi Balittri. 21 (2): $25-28$

[19] Towaha, J., E.D.A. Anggraini, dan Rubiyo. 2012 Keragaan mutu biji kakao dan produk turunannya pada berbagai tingkat fermentasi: Studi kasus di Tabanan, Bali.

[20] Utami, R.,R. 2018. Antioksidan biji kakao: pengaruh fermentasi dan penyangraian terhadap perubahannya (ulasan). J. Industri Hasil Perkebunan. 13 (2): 75-85

[21] Wahidin, Tamrin, dan E. Danggi, 2017. Pengaruh bahan penyusun produk cokelat batangan terhadap waktu leleh dan uji organoleptik. (JSTP) ISSN: 2527-6271. J. Sains dan Teknologi Pangan. 2 (1): 285 - 297.

[22] Wells, M.A. 2009. Chocolate crumb. in industrial chocolate manufacture and use. 4th edition. Beckett, S.T (ed). Blackwell Publishing Ltd. ISBN: 978-1-405-13949-6. 101-119 pp. 